Original article

\title{
Physical changes in heat-treated whole milk powder
}

\author{
Robert BAECHLER*, Marie-France ClERC, Stéphane ULRICH, Sylvie BENET \\ Nestlé Research Center, Nestec Ltd., Vers-chez-les-Blanc, CH-1000 Lausanne 26, Switzerland
}

Published online 14 June 2005

\begin{abstract}
The heat treatment of milk powders during food manufacturing induces physical and chemical modifications that are governed by material phase transitions. The main aim of this work was to describe the heat-induced physical changes occurring in whole milk powder (WMP). The study was based on increasing the water activity $\left(\mathrm{a}_{\mathrm{w}}\right)$ of the powder in order to relate the glass transition temperature ( $\mathrm{Tg})$ to the parameters resulting in changes in physical properties. Colour changes in milk powder due to non-enzymatic browning (NEB) were monitored by spectrophotometry based on the CIE L*a*b* function. Changes in particle structure were investigated by scanning electron microscopy (SEM). WMPs at low and high water activities $(0.28$ and 0.35$)$ were heated in closed tubes and their physical properties $\left(\mathrm{a}_{\mathrm{w}}\right.$, lactose crystallisation and free fat release) monitored. The results showed that the kinetics of lactose crystallisation and the resulting increase in $\mathrm{a}_{\mathrm{w}}$ were clearly influenced by the Tg, modulated here by the water content of WMP at the time of heat treatment. The kinetics of free fat release was related to the trend of lactose crystallisation. SEM showed that the free fat was released onto the particle surfaces and formed a fat layer covering the lactose crystals. Porosity then resulted inside the powder matrix due to empty cavities formerly occupied by fat globules. In addition, the chemical reactivity of WMP expressed by colour changes showed a delay in triggering the NEB reaction in milk powder at low water content only. The results of this study showed that the heat treatment of WMP under specific process parameters $\left(\mathrm{a}_{\mathrm{w}}\right.$, temperature and time) enables not only modulation of free fat release and browning but also changes in the microstructure of the powder particles.
\end{abstract}

whole milk powder / heat treatment / free fat / crystallisation / browning

Résumé - Changements physiques de la poudre de lait entier traitée thermiquement. Le traitement thermique des poudres de lait inhérent à certains procédés de fabrication alimentaire induit des modifications physiques et chimiques, gouvernées par les transitions de phase du matériau. L'objectif principal de ce travail a été de décrire les changements physiques dans la poudre de lait entier (WMP) induits par le traitement thermique. L'approche de cette étude était basée sur l'augmentation de l'activité d'eau $\left(\mathrm{a}_{\mathrm{w}}\right)$ de la poudre afin de relier la température de transition vitreuse ( $\mathrm{Tg}$ ) aux variations de paramètres permettant le changement des propriétés physiques. Le changement de couleur de la poudre de lait dû au brunissement non-enzymatique (NEB) a été mesuré en utilisant la méthode spectrophotométrique basée sur la lecture CIE des fonctions L*a*b*. La modification de la structure des particules a été examinée par microscopie à balayage électronique (SEM). Deux WMP à basse et haute $\mathrm{a}_{\mathrm{w}}(0.28$ et 0.35$)$ ont été chauffés dans des tubes hermétiques et les propriétés physiques telles que $\mathrm{a}_{\mathrm{w}}$, cristallisation du lactose, matière grasse libre, ont été suivies. Les résultats ont montré que la cinétique de cristallisation du lactose et l'augmentation intrinsèque de l' $\mathrm{a}_{\mathrm{w}}$ étaient clairement influencées par la valeur de $\mathrm{Tg}$, modulée ici par la teneur en eau de la poudre au moment du traitement thermique. La cinétique de libération de la matière grasse était

* Corresponding author: robert.baechler@rdls.nestle.com 
reliée à l'évolution de la cristallisation du lactose. Les images SEM ont montré que la matière grasse était libérée vers la surface des particules et formait une couche recouvrant les cristaux de lactose. Ainsi, une nouvelle porosité a été créée à l'intérieur des particules, provenant des cavités précédemment occupées par les globules de graisse. De plus, la réactivité chimique du WMP, exprimée ici par l'évolution du brunissement, a montré un retard du démarrage de la réaction NEB pour la poudre à basse teneur en eau uniquement. Les résultats de cette étude montrent qu'un traitement thermique contrôlé du WMP appliqué dans des valeurs de paramètre spécifiques $\left(\mathrm{a}_{\mathrm{w}}\right.$, température, temps) est à même de moduler non seulement la libération de la matière grasse et le brunissement mais aussi la modification de la microstructure de la poudre.

poudre de lait entier / traitement thermique / matière grasse libre / cristallisation / brunissement

\section{INTRODUCTION}

The process used to manufacture whole milk powder (WMP) has a large impact on its suitability for confectionery. Flavour [11] and mechanical energy reduction [1] appear to be the main issues in the choice of free fat milk powder for the manufacture of chocolate. Additionally to the amount of energy consumed, process economy implies a complex of technological variables such as the decrease in viscosity and the amount of cocoa butter required $[2,11]$. Milk powder produced by roller-drying is usually preferred for the manufacture of milk chocolate $[3,11]$. The main advantage of rollerdried whole milk powders compared with spray-dried is the higher free fat content, $>90 \%$ in roller-dried milk versus $<10 \%$ in spray-dried milk [9]. However, spray-drying is today the most common process for producing WMP for the chocolate industry.

In spray-dried WMP, amorphous lactose forms a continuous matrix in which proteins, fat and air are dispersed. During the spray-drying process, the rapid evaporation of water results in the formation of metastable amorphous lactose. If milk powder is exposed to high relative humidity, increased temperature or both, the metastable amorphous lactose proceeds to the $\mathrm{Tg}$ in the rubbery region where the lactose could crystallise in $\beta$ form $[10,12]$. Saito [10] concluded that the deposits on WMP surface were fat that migrated from the interior of the milk particle. Expulsion of fat is accompanied by lactose crystallisation that totally changes particle structure $[8,13]$. A strong correlation between free fat content and particle porosity of WMP was observed by Buma [5,6]. Microstructure changes and the presence of lactose crystals can be easily evaluated by scanning electron microscopy (SEM) [5-7, 13].

Vuataz [12] demonstrated by NIR technology that WMP stored under adverse conditions $(2.5-4.0 \%$ water content heated for some hours at $70{ }^{\circ} \mathrm{C}$ ) always exhibits a large amount of beta anhydrous lactose crystals. Buma $[5,6]$ showed that the interior of particles of spray-dried WMP is accessible to gases and liquids if the lactose has crystallised and formed a fine network of interstices between crystals. Lactose crystallisation in WMP results in particle aggregation, formation of new pores, increased free fat and particle density, and reduced surface area and pore volume [1].

As reported elsewhere in the literature, non-enzymatic browning (NEB) is affected by the glass transition phenomenon. As the system changes from a glassy to a rubbery state, the rate of browning increases sevenfold. The rate of browning increases as water activity $\left(\mathrm{a}_{\mathrm{w}}\right)$ increases from 0.33 to 0.54 , but then reaches a plateau with further increase in $\mathrm{a}_{\mathrm{w}}$ [4]. Other authors suggested that the state of the system influences the diffusion and interaction of reactants and appears to be the rate-limiting step with respect to the kinetics of NEB. The aim of this present work was to assess the fat release and other physical changes as well as NEB in heat-treated WMP at low $\left(a_{w}\right.$ $0.28)$ and high $\left(\mathrm{a}_{\mathrm{w}}\right.$ 0.35) water content. Changes in the microstructure were evaluated by SEM. NEB was followed by measurement of the total colour evolution of the powder. 


\section{MATERIALS AND METHODS}

\subsection{Whole milk powder}

Whole milk powder (WMP) was supplied by Nestlé S.A. (Vevey, Switzerland). The overall characteristics of the powder were representative of standard milk powder and contained 26\% total fat and 3\% water content $\left(\mathrm{a}_{\mathrm{w}} 0.28\right)$. This raw material was used as the sample with the lowest humidity.

The second powder with a higher water content was prepared by placing the WMP in a sealed glass desiccator containing saturated salt $\mathrm{K}_{2} \mathrm{CO}_{3}$. Water uptake and $\mathrm{a}_{\mathrm{w}}$ were monitored until the powder reached $\mathrm{a}_{\mathrm{w}}=0.35$. Then, WMP samples were placed in a sealed opaque aluminium bag and stored for at least one week in order to equilibrate the water repartition within the matrix. The $a_{w}$ was then controlled immediately before heat treatment of the powder.

\subsection{Powder heat treatment}

Heating of powders was carried out in sealed stainless steel tubes in a Tubule Heating Apparatus (THA). Five tubes of $12 \mathrm{~cm}^{3}$ capacity were placed together in the heating chamber where hot water was used as heating medium. The temperature was monitored by a sensor directly placed in the top tube. The tubes were heated at $90^{\circ} \mathrm{C}$ for $70 \mathrm{~min}$. One tube was removed from time to time during the heating period and cooled in an ice bath. Then, the powder was rapidly transferred from the tube into a sealed bag and stored at $15^{\circ} \mathrm{C}$. Sample analysis started after $2 \mathrm{~d}$ of storage.

\subsection{Analytical methods}

\subsubsection{Water activity}

$\mathrm{A}_{\mathrm{W}}$ measurements were carried out at $25^{\circ} \mathrm{C}$ with a Hygroskop model DT instrument (Rotronic, Bassersdorf, Germany) according to the official method of analysis $\mathrm{N}^{\circ} 978.18$ of AOAC International [14]. All $\mathrm{a}_{\mathrm{w}}$ data were corrected using a quadratic equation obtained using 5 standard saturated salts $\left(\mathrm{a}_{\mathrm{w}}\right.$ : $0.111,0.225,0.328,0.432$ and 0.529).

\subsubsection{Lactose crystallisation}

The presence or absence of lactose crystals was determined by direct microscopic examination of the powders with a binocular system under polarised light. This method does not determine the lactose crystallisation level.

Gas Capillary Chromatography (GCC) assessed the degree of lactose crystallisation. The $\beta / \alpha$ lactose ratio $(R)$ was a calculation of the degree of crystallisation $(\% C R)$ according to the following formula:

$$
C R(\%)=100 \times \frac{(R a-R) \times(1+R c)}{(R a-R c) \times(1+R)}
$$

where: $R a=$ amorphous $\beta / \alpha$ lactose ratio $(R a \simeq 1.25) ; R c=$ crystallised $\beta / \alpha$ lactose ratio ( $R c$ is not taken into account when only beta lactose crystallises); $R=$ total $\beta / \alpha$ lactose ratio measured in the sample.

\subsubsection{Free fat analysis}

In milk powder "free fat" is defined as the fat present on the surface and outside of the milk powder particles. This is determined gravimetrically by fat extracted under mild shaking with hexane for $5 \mathrm{~min}$ at room temperature.

\subsubsection{Microstructure evaluation}

Scanning electron microscopy (SEM) was used to investigate physical changes in particle structure during the heat treatment of WMP. This technology (Philips EM 505 scanning electron microscope) visualises lactose crystals and free fat on the surface of milk powder particles.

\subsubsection{Colour measurement}

Non-enzymatic browning (NEB) of the powder was monitored using a GretagMacBeth CE-XTH spectrophotometer. The spectrophotometer gives colour output as CIE L*a*b* functions along with the derived parameters chroma $\mathrm{C}^{*}$, and hue angle $\mathrm{h}$. Evolution of the colour was assessed by the total colour difference $\Delta \mathrm{E}^{*}$ (or $\mathrm{DE}^{*}$ ) calculated by the change in each parameter $\left(\Delta L^{*}, \Delta a^{*}, \Delta b^{*}\right)$ : $\mathrm{DE}^{*}=\sqrt{\Delta L^{* 2}+\Delta a^{* 2}+\Delta b^{* 2}}$. $\mathrm{DE}^{*}$ has no sign and only gives the magnitude of a colour difference and not its direction. 

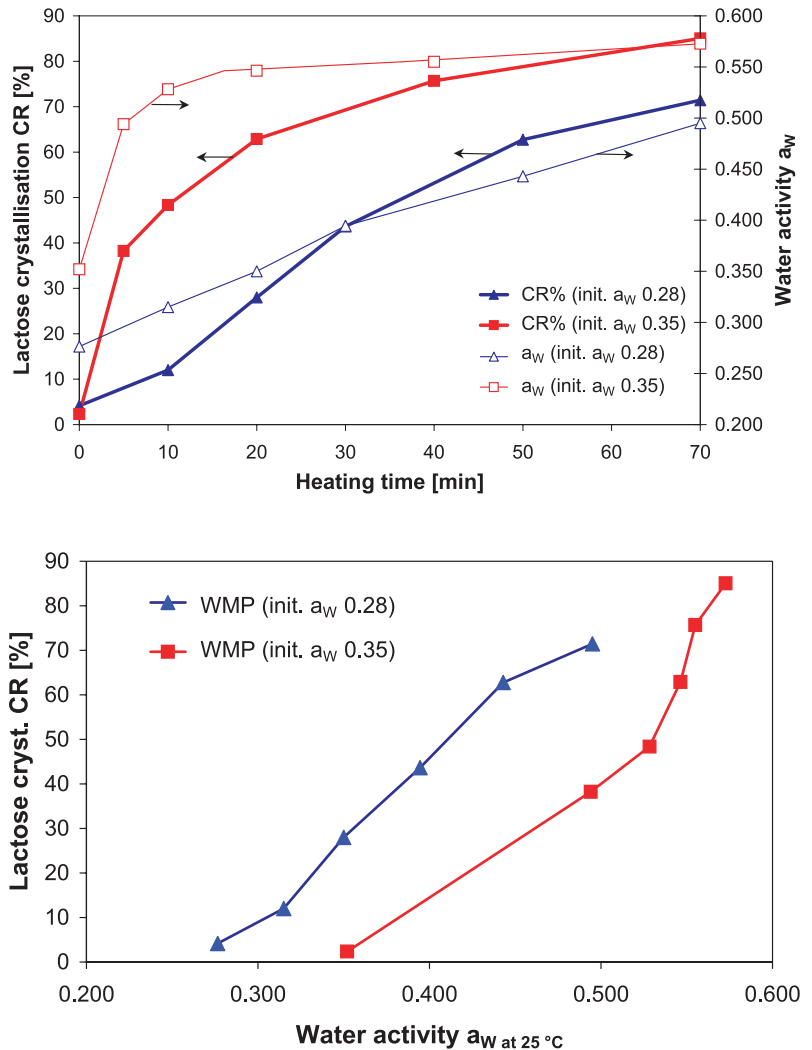

Figure 1. Evolution of lactose crystallisation and water activity of WMP for two initial levels of $\mathrm{a}_{\mathrm{w}}(0.28 ; 0.35)$, heat-treated at $90{ }^{\circ} \mathrm{C}$ during $70 \mathrm{~min}$.

\section{RESULTS AND DISCUSSION}

\subsection{Repeatability}

Each serial of heat treatment was duplicated. Like this, analytical data of each point was issued from the average of two values. The differences between the largest and the smallest values (range) were in all cases less than $5 \%$ of the average. Thus, the physical evolutions of heat-treated WMP assessed in the present study showed a good repeatability.

\subsection{Evolution of lactose crystallisation and water activity}

The results showed that the initial $\mathrm{a}_{\mathrm{w}}$ has an important impact on the speed and extent of lactose crystallisation (Fig. 1). WMP heated at $90{ }^{\circ} \mathrm{C}$ for $70 \mathrm{~min}$ induced an increase in the total $\beta / \alpha$ ratio from 1.34 to 6.87 at low initial $\mathrm{a}_{\mathrm{w}}(0.28)$ and 14.03 at higher initial $\mathrm{a}_{\mathrm{w}}(0.35)$, respectively. By increasing the initial $\mathrm{a}_{\mathrm{w}}$ of WMP to 0.35 , the evolution of lactose crystallisation speeded up to reach $63 \%$ after 20 min while only $28 \%$ was crystallised for the WMP at low $\mathrm{a}_{\mathrm{w}}(0.28)$ (Fig. 1). As described by Vuataz [12], heat treatment of WMP in solid state condition and under static process exhibited mainly anhydrous lactose crystals in the $\beta$ form. As previously reported by other authors, there is a clear correlation between the extent of lactose crystallisation and the evolution of $\mathrm{a}_{\mathrm{w}}$ during the heat treatment of milk powder (Fig. 2). The two phenomena are linked since water is released upon lactose crystallisation. Water arising from lactose crystallisation remains in the matrix (powder placed in sealed tubes) and increases the overall $\mathrm{a}_{\mathrm{w}}$ of the powder. 

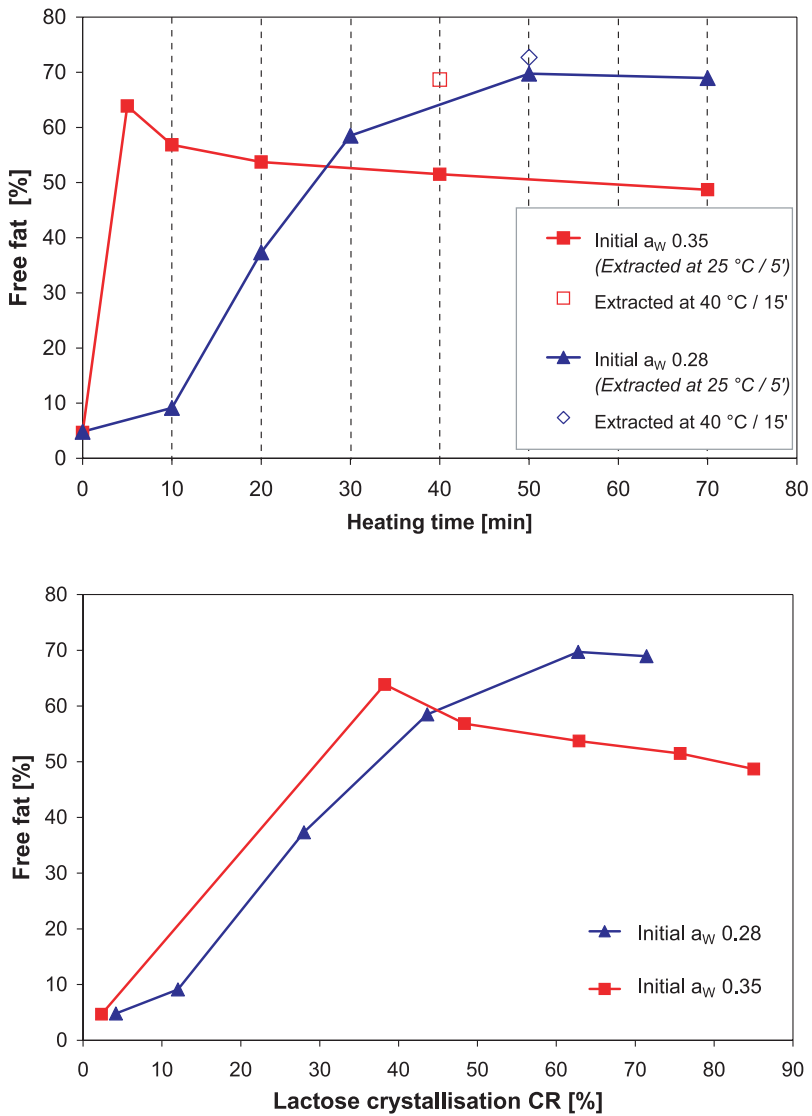

Figure 3. Evolution of free fat release of WMP at low (0.28) and high $(0.35) \mathrm{a}_{\mathrm{w}}$, both heattreated at $90^{\circ} \mathrm{C}$ for $70 \mathrm{~min}$.

Figure 4. Correlation between the evolution of lactose crystallisation and free fat released during the heat treatment of WMP at $90^{\circ} \mathrm{C}$.

\subsection{Free fat release}

The increase in initial $\mathrm{a}_{\mathrm{w}}$ from 0.28 to 0.35 increased the speed of lactose crystallisation as well as the induced fat release. A free fat range of 65 to $70 \%$ was reached after 5 min with the high initial $\mathrm{a}_{\mathrm{w}}(0.35)$ powder while 50 min was necessary at low $\mathrm{a}_{\mathrm{w}}(0.28)$ (Fig. 3). However, by extracting fat at $25^{\circ} \mathrm{C}$ with hexane for a short time $(5 \mathrm{~min})$, the results showed in the case of the higher $a_{w}$ a decrease in free fat following the first strong fat release (Fig. 3). This phenomenon could be explained by the rapid formation of strong fissures and roughness on the particle surface where free fat could be located [5, 6]. Results of fat extraction obtained for powders drastically changing their structure during heat treatment are not comparable $[5,6]$. Thus, by changing the extraction conditions $\left(40{ }^{\circ} \mathrm{C}\right.$ instead of $25^{\circ} \mathrm{C} ; 15 \mathrm{~min}$ instead of $5 \mathrm{~min}$ ), the results showed an evolution towards a plateau close to $70 \%$ free fat (Fig. 3). It seems that free fat accessibility by the solvent depends strongly on the surface state of the milk particle. The rate of fat release onto the surface of powder particles during the heat treatment of WMP was nevertheless correlated to the evolution of lactose crystallisation (Fig. 4). The present results established this relationship for milk powders at low and high initial $\mathrm{a}_{\mathrm{w}}$. This confirms observations made by other authors $[1,8,13]$. This method of free fat delivery from WMP seems to be a simple and efficient process, allowing the amount of cocoa butter in the chocolate mass to be reduced while insuring the required viscosity. 


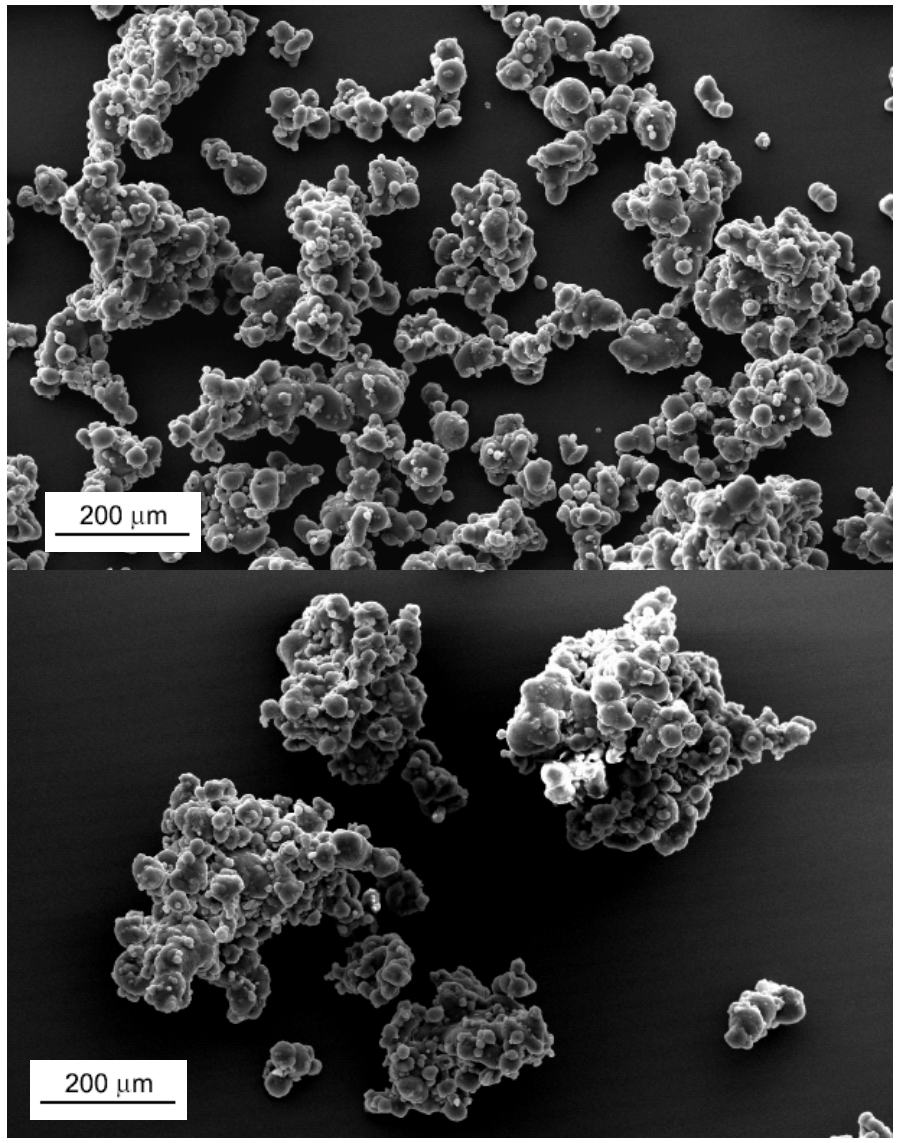

Figure 5. SEM image of WMP at low initial $\mathrm{a}_{\mathrm{w}}$ $(0.28)$, before and after 70 min of heat treatment at $90{ }^{\circ} \mathrm{C}$.

\subsection{Change in WMP microstructure}

The WMP microstructure is affected by lactose crystallisation [1,5-7]. The analysis of milk particles by SEM showed a significant change in structure during heat treatment. The process induced powder agglomeration. This effect was observed more particularly for WMP heat treated at low initial $\mathrm{a}_{\mathrm{w}}(0.28)$ (Fig. 5). Heat-induced lactose crystallisation was observed on the milk particle surface when lactose crystals were coated by the free fat layer (Fig. 6). The cross-section of the particle showed an increase in porosity in the powder matrix due to fat release onto the surface (Fig. 7). The image showed large cavities of air bubbles formed during spray-drying. The new smaller cavities represent the sites formerly occupied by fat. Comparing milk powder particles before and after fat release showed a drastic increase in the porosity of the matrix (Fig. 7). Thus, this work revealed the possibility of creating porous texture inside whole milk powder by heat treatment under controlled conditions $\left(\mathrm{a}_{\mathrm{w}}\right.$, temperature and time) inducing lactose crystallisation and fat release from the matrix onto the surface.

\subsection{Colour change of WMP}

The change in colour occurring during the heat treatment of WMP is an expression of non-enzymatic browning (NEB), that is the indicator of the advanced Maillard reaction. The progression of NEB was followed 


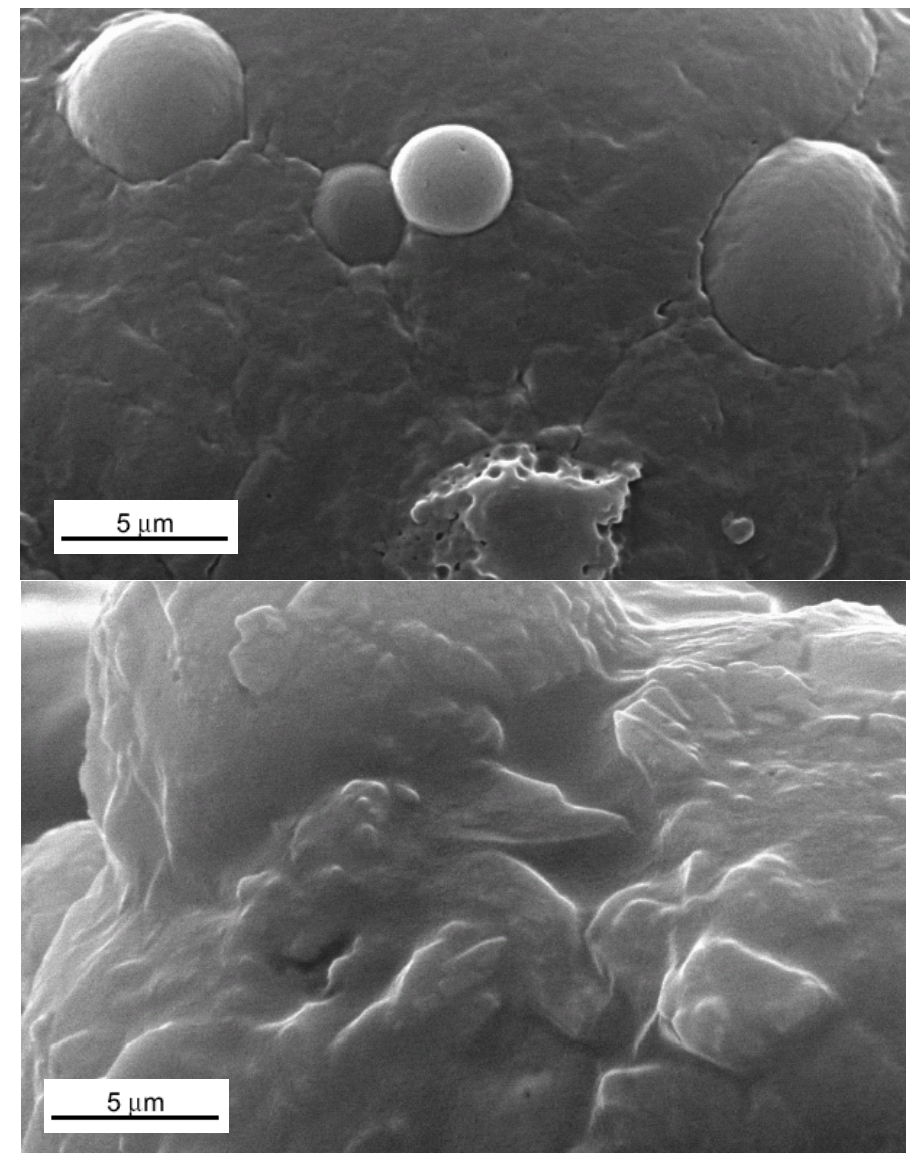

Figure 6. SEM image showing the surface of WMP at high initial $\mathrm{a}_{\mathrm{w}}$ (0.35), before and after the heat-induced lactose crystallisation and free fat release $\left(90{ }^{\circ} \mathrm{C}\right.$; $70 \mathrm{~min})$.

during the heating process by measuring the total colour evolution of WMP. Browning of WMP was well determined by the spectrophotometric CIE $\mathrm{L}^{*} \mathrm{a} * \mathrm{~b}^{*}$ functions. Both WMPs showed the same browning display when the relation between the $a^{*}$ (green - red) and b* (blue - yellow) values were drawn (Fig. 8). The total colour evolution (DE*) was assessed for WMP at low (0.28) and high (0.35) $\mathrm{a}_{\mathrm{w}}$. However, the colour change was different at low $\mathrm{a}_{\mathrm{w}}$ than at higher. The results showed a delay in triggering the browning for the WMP at low initial $\mathrm{a}_{\mathrm{w}}(0.28)$. At high initial $\mathrm{a}_{\mathrm{w}}(0.35)$, browning started as soon as heating at $90^{\circ} \mathrm{C}$ started. Later during the heat treatment, regardless of the increase in $\mathrm{a}_{\mathrm{w}}$, the evolution of NEB stayed constantly linear
(Fig. 9). An initial $\mathrm{a}_{\mathrm{w}}$ of 0.35 seemed to be the minimum required level for the spontaneous start of browning at $90{ }^{\circ} \mathrm{C}$.

\section{CONCLUSION}

The present study assessed the key role of initial water activity on the physical changes occurring in whole milk powder during heat treatment under solid-state conditions. The phase diagram of whole milk powder was the key for managing the process parameters, allowing the phase transition of WMP above the Tg. The Tg of WMP at both low $\left(\mathrm{a}_{\mathrm{w}} 0.28\right)$ and high $\left(\mathrm{a}_{\mathrm{w}} 0.35\right)$ water activities were low enough to allow 


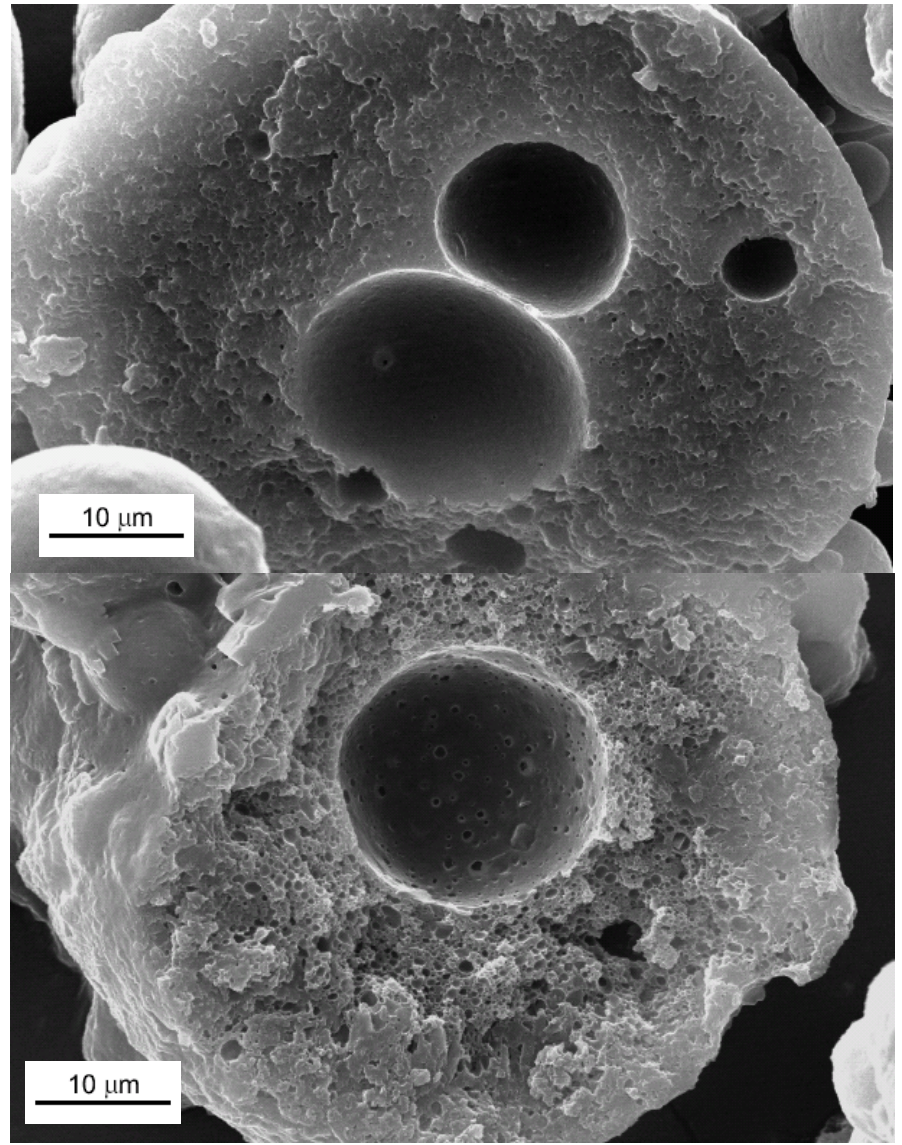

Figure 7. SEM image showing the internal porosity of WMP at high initial $\mathrm{a}_{\mathrm{w}}(0.35)$, before and after $70 \mathrm{~min}$ of heat treatment at $90^{\circ} \mathrm{C}$. rapid lactose crystallisation in the $\beta$ form. The kinetics of free fat release was clearly related to lactose crystallisation. The heat treatment of WMP under specific process parameters (water content, temperature and time) enabled not only modulation of free fat release but also the change in microstructure and colour in powder particles.

When free fat was released onto the particle surface, a substantial porosity was then created inside the powder matrix by the empty cavities formerly occupied by fat globules. SEM technology showed that the process induced powder agglomeration and formation of lactose crystals on the particle surface. Nevertheless, an increase in initial $\mathrm{a}_{\mathrm{w}}$ to 0.35 is recommended to spontane- ously trigger fat release above $70 \%$ when WMP is heated at $90{ }^{\circ} \mathrm{C}$. The results confirm the importance of controlling the water activity of WMP before the heat treatment, especially when free fat availability is the target of product delivery. After heating, the WMP stayed in the powder form whatever the level of fat freeing. The trigger of browning (NEB) was delayed at the low initial level of $\mathrm{a}_{\mathrm{w}}$. When the initial $\mathrm{a}_{\mathrm{w}}$ was 0.35 , NEB spontaneously triggered upon heating at $90{ }^{\circ} \mathrm{C}$. When the advanced Maillard reaction started, the physical evolution of WMP did not affect the speed of browning.

Thus, heat treatment of whole milk powder under increased water activity could bring benefits to simplify and shorten the 

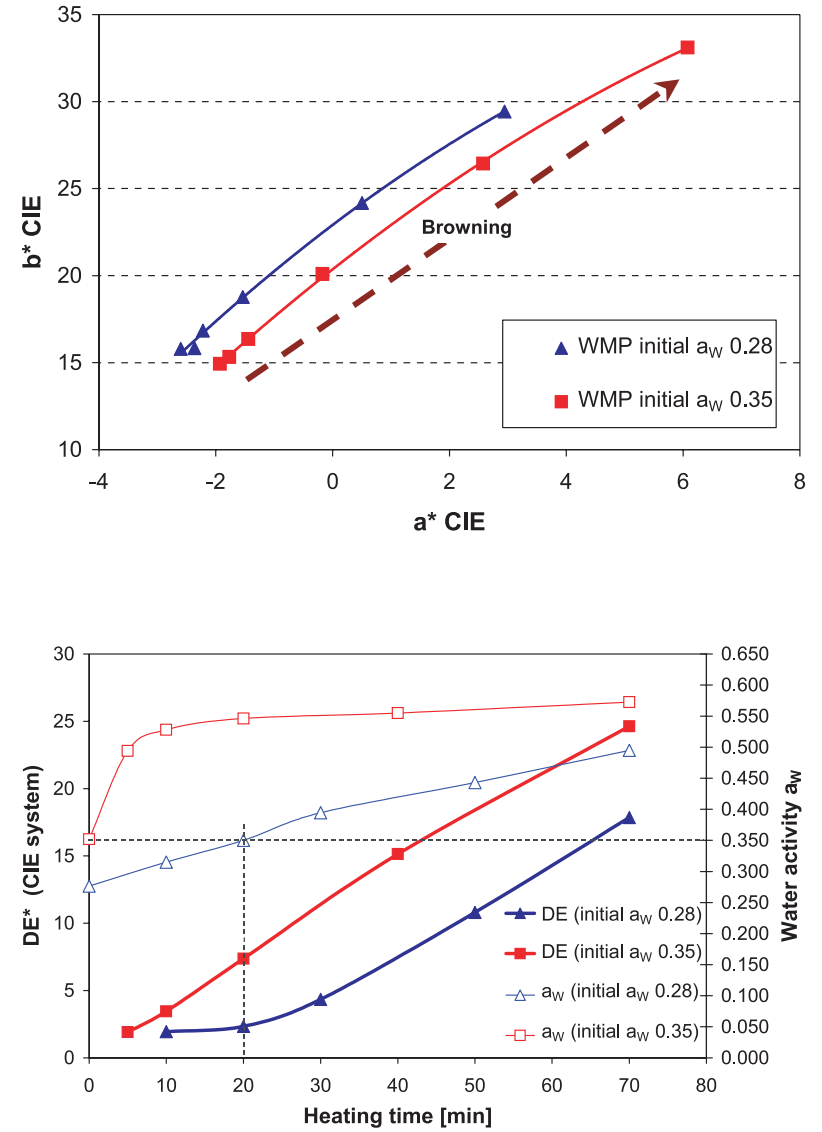

Figure 8. Browning range of WMP at low (0.28) and high $(0.35) \mathrm{a}_{\mathrm{w}}$, expressed by the extent of $a^{*}$ and $b^{*}$ value during $70 \mathrm{~min}$ of heat treatment at $90^{\circ} \mathrm{C}$.

Figure 9. Evolution of total colour difference $\left(\mathrm{DE}^{*}\right)$ and $\mathrm{a}_{\mathrm{w}}$ of WMP at low (0.28) and high $(0.35) \mathrm{a}_{\mathrm{w}}$, both heat-treated at $90{ }^{\circ} \mathrm{C}$ during $70 \mathrm{~min}$. process of free fat delivery. The higher availability of free fat from heat-treated WMP could allow the amount of cocoa butter in the chocolate mass to be reduced while reaching the required viscosity.

\section{REFERENCES}

[1] Aguilar C.A., Ziegler G.R., Physical and microscopic characterization of dry whole milk with altered lactose content. 2: Effect of lactose crystallization, J. Dairy Sci. 77 (1994) 1198-1204.

[2] Attaie H., Breitschuh B., Braun P., Windhab E.J., The functionality of milk powder and its relationship to chocolate mass processing, in particular the effect of milk powder manufac- turing and composition on the physical properties of chocolate masses, Int. J. Food Sci. Technol. 38 (2003) 325-335.

[3] Beckett S.T., Chocolate, function of milk, in: Roginski H., Fuquay J.W. (Eds.), Encyclopedia of Dairy Science, Elsevier Science Ltd, London, UK, 2002, pp. 444-449.

[4] Bell L.N., Kinetics of non-enzymatic browning in amorphous solid systems: Distinguishing the effects of water activity and the glass transition, Food Res. Int. 28 (1996) 591-597.

[5] Buma T.J., Free fat in spray-dried whole milk. 2: an evaluation of methods for the determination of free-fat content, Neth. Milk Dairy J. 25 (1971) 42-52.

[6] Buma T.J., Free fat in spray-dried whole milk. 8: the relation between free-fat content and particle porosity of spray-dried whole milk, Neth. Milk Dairy J. 25 (1971) 123-140. 
[7] Caric M., Kalab M., Effects of drying techniques on milk powders quality and microstructure: a review, Food Microstruct. 6 (1987) 171-180.

[8] Fäldt P., Bergenstahl B., Spray-dried whey protein/lactose/soybean oil emulsions. 1: surface composition and particle structure, Food Hydrocolloids 10 (1996) 421-429.

[9] Reimerdes E.H., Mehrens H.-A., Milk, in: Becket S.T. (Ed.), Industrial chocolate manufacture in use, Blackie \& Son Ltd, London, UK, 1988, pp. 47-57.

[10] Saito Z., Particle structure in spray-dried whole milk and in instant skim milk powder as related to lactose crystallization, Food Microstruct. 4 (1985) 333-340.
[11] Verhey J.G.P., Physical properties of dried milk in relation to chocolate manufacture, Neth. Milk Dairy J. 40 (1986) 261-268.

[12] Vuataz G., The phase diagram of milk: a new tool for optimising the drying process, Lait 82 (2002) 485-500.

[13] Würsch P., Rosset J., Köllreutter B., Klein A., Crystallization of beta-lactose under elevated storage temperature in spray-dried milk powder, Milchwissenschaft 39 (1984) 579-582.

[14] Prosky L., Water activity of canned vegetables, in: Horwitz W. (Ed.), Official Methods of Analysis of AOAC International 17th edn., AOAC International, Gaithersburg, USA, 2000 , locator number 42.1.03. 